\title{
The Relationship among Anti-Corruption Campaigns, Political Connections, and Information Asymmetry on Firm Performance:
}

\author{
Evidence from China
}

\author{
Han-Fang Tsai \\ Department of Finance \\ Feng Chia University \\ Taichung, Taiwan (ROC)
}

\author{
Tsui-Jung Lin, Lien-Wen Liang \\ Department of Banking and Finance \\ Chinese Culture University \\ Taipei, Taiwan (ROC)
}

\author{
Nur Imamah* \\ Department of Business Administration \\ University of Brawijaya \\ Malang, Indonesia \\ *nurima_fia@ub.ac.id
}

\begin{abstract}
This article discusses the impact of anti-corruption campaigns, political connections and information asymmetry on firm performance, and Shanghai and Shenzhen listed companies in mainland China are used as a sample from 2008 to 2018. This study finds that there is a negative relation between political connections and firm performance. Further, this article adds the discussion of anti-corruption clauses. The sample group with high information asymmetry has a positive performance. The research results of this paper contribute to corporate governance and management practices in emerging markets, that is, when managers are embedded in the interests of political relations due to imperfect markets, the potential costs and benefits of political connections need to be considered and taken into account.
\end{abstract}

Keywords-anti-corruption campaigns, political connections, information asymmetry, firm performance, China

\section{INTRODUCTION}

Extant studies have conflicting opinions toward how political connections affect firm performance. Bertrand et al. examine the relationship between political connections and firm performances in French companies [1]. The results indicate that political connections affect management decisions, and politically connected companies benefit from politics. Xu et al. suggest that family enterprises can enhance company performances and mitigate under-investments through political connections [2]. In contrast, Faccio and Parsley argue that political influence during elections may increase labor and employment costs and decrease firm performance [3]. Moreover, the information asymmetry results from political connections is a key determinant of company performances. Chen et al. contend that politically connected firms are allowed to have more managerial discretion in financial disclosure [4]. This increases information asymmetry between management and financial analysts, and as a result, the forecasts from analysts about politically connected companies are less accurate than those without political connections. Consequently, political connections will aggravate agency problems between investors and managers and thereby, higher information asymmetry.

In practice, political connections of a company are typically materialized in corruptions. $\mathrm{Hu}$ and Guo estimate that corruptions consume $4 \%$ to $8 \%$ of China's GDP [5]. Corruptions are deemed to hinder economic growth by directing capital, efforts, and talents from the activity of higher productivity to the political pursuit of rent-seeking [6,7]. The China-specific ownership structure also encourages corruptions. It is commonplace that the Chinese government is the controlling shareholder or the largest shareholder of listed companies in China. The reform to curb corruptions stateowned enterprises in China is a must. Under any circumstances, state-owned enterprises and corruptions are highly corrected. This is particularly reflected by entertainment and travel costs (ETC), spending by or transactions among senior insiders. Government officials are the main target of anti-corruption campaigns, given the purpose of suppressing their overspending and discouraging superficial formalities. It is hoped that government officials stay in tune with grassroots so that resources can be more efficiently allocated. In the short term, the implementation of anti-corruption clauses hurts the value of prior investments in these relationships and detriments 
the firm's value [8]. Over the long run, the execution of anticorruption clauses limits the transactions at the expense of shareholders' interest, enhances the transparency and the value of the company.

In brief, this paper serves as an additional contribution to the literature on the relation between anti-corruptions and ownership structures. Hu et al. find that the value of politically connected independent directors declines dramatically after anti-corruption campaigns [9]. This indicates that the implementation of anti-corruption clauses can effectively eliminate board members' political connections and mitigate the damage of political connections on company performances. This paper builds on top of the conclusion by adding the exploration of different ownership structures. The ownership structures of listed companies in China are distinctively different from those in developed economies [10]. Many listed companies in China are state-owned enterprises and have three types of ownerships: government owners, institutional investors, and retail investors [11]. Also, the holdings of a controlling shareholder or the largest shareholder are significantly larger than the holdings of the second-largest shareholder [12]. There are huge variances in the restrictions and capabilities of accessing external resources as a result of ownership structures. This is the reason for different needs and objectives in the seeking of political connections. Wang suggests that independent directors with political affiliations can enhance the value of listed private holdings companies, but not the value of state-controlled companies [13]. Therefore, the government's crackdown on corruption should have different effects on companies' performance with different ownership structures.

\section{HYPOTHESIS DEVELOPMENT}

Ke, Liu, and Tang highlight the profound but negative effects of the anti-corruption campaign on listed companies' performance [14]. This is particularly noticeable when comparing the listed companies selling luxury products/services in the alcohol, restaurants, and hotels sectors vs the companies not selling luxury products/services. The abnormal reaction from the stock market is observed before and after the anti-corruption event. The difference between the companies' sales offering luxury products/services and the sales of the companies offering non-luxury products/services is economically significant, at $11.90 \%$. Compared to peers not offering luxury products/services, the companies offering luxury products/services witness a $7.327 \%$ decline in operating margin and asset sizes from the years 2011-2012 before corruption crackdown to the years 2013-2014 post corruption crackdown. The change in the profitability of the companies selling luxury products/services indicates weaker performances for the companies with excess information asymmetry and a lack of information transparency due to political connections. Government officials assume shareholders are ignorant and misuse company resources to seek personal gains (in the form of bribery), at the expense of firm values. Therefore, this paper believes that anti-corruption clause affects the relation among political connections; there is no explanation how anticorruption might affect the political connections, information asymmetry and company performances. The following hypothesis is developed:

H1: The anti-corruption clause affects the relation among political connections, information asymmetry and company performances.

\section{SAMPle SElection AND Methodology}

This paper samples the companies listed in China in 20082018 from the China Stock Market and Accounting Research Database (CSMAR) by eliminating financial institutions and the companies with missing data in the exploration of the influence of the anti-corruption clause, ownership structures, political connections, and information asymmetry on company performances. The final sample consists of 5,513 firm-years observations of listed companies. The first step is to examine the sample distribution and characteristics with descriptive statistics. This is followed with an analysis on the corrections between variables and steps to mitigate collinearity problems. Finally, a cross-sectional regression analysis is conducted to validate the research hypotheses.

This paper adopts the definition of political connections by Boubakri [15], Faccio [3], Fan et al. [16] and Su et al. [17]. A dummy variable is set up, with 1 indicating political connections that an independent board director was or is a member of CPPCC (Chinese People's Political Consultative Conference) or National People's Congress (NPC) or officials at provincial levels or above. The dummy variable is 0 if there are no political connections. The number of politically connected independent directors is added up, then divided by the board's size, to serve as a measurement of political connectivity.

To gauge the influence of information asymmetry on company performances, this paper refers to $\mathrm{Li}$ and Zhao [18] and Drobetz et al. [19] by using the standard deviation of errors in earnings forecasts by analysts.

To validate the research hypotheses, this paper further divides the sample into two groups, one group with high information asymmetry levels, and another group with low levels of information asymmetry, by using the median as the cutoff point.

The Chinese government began to crack down on corruption since 2013. Among all the measures, Document No. 18 has the most profound influence on corporate operations. This document stipulates government officials cannot hold any key positions in companies. Retired officials are not allowed to join companies during the first three years of retirement. The part-time jobs taken by retired government officials should not come with salaries or benefits unless they forgo their jobs by working full-time for companies. Document No. 18 also prohibits government officials from exercising their political influence to create preferential business advantages for companies [9]. This paper defines the 
year 2013 as the anti-corruption year and test the hypotheses based on statistical differences of the two subgroups of the sample, one for 2008-2012 and the other for 2014-2018.

In reference to $\mathrm{Hu}$ et al. [9], this paper added control variables such as Age (firm age), Size (firm size), Sales Growth (annual growth of revenues), Board Size (number of directors on the board), IndBoard Ratio (board independence), ROA (return on assets), Booklev (leverage), Cash Flow (cashflows), Tangibility (tangible assets).

\section{EMPIRICAL RESULTS}

Table 1 shows the descriptive statistics of all variables. As shown in the table, the mean (median) of company performances (TOBIN's Q) is 3.496 (2.804), indicating the growth potential of listed companies in China consistent with the trend in emerging markets. The mean (median) of political connections (POL) is 0.173 (0.000), suggesting that $17.3 \%$ of the independent directors in a company are politically connected. The mean (median) of information asymmetry (ASY_M) is 0.458 (0.000), indicating a high level of information asymmetry in general.

TABLE I. DESCRIPTIVE STATISTICS

\begin{tabular}{|l|l|l|l|l|l|l|}
\hline \multicolumn{1}{|c|}{ Variables } & Observations & \multicolumn{1}{c|}{ Mean } & \multicolumn{1}{c|}{ Median } & \multicolumn{1}{c|}{ Maximum } & \multicolumn{1}{c|}{ Minimum } & \multicolumn{1}{c|}{ Std. Dev. } \\
\hline Tobin's Q & 5513 & 3.496 & 2.804 & 47.188 & 0.462 & 2.615 \\
\hline POL & 5513 & 0.173 & 0.000 & 3.333 & 0.000 & 0.258 \\
\hline ASY_M & 5513 & 0.458 & 0.000 & 1.000 & 0.000 & 0.498 \\
\hline ANTI & 5513 & 0.717 & 1.000 & 1.000 & 0.000 & 0.450 \\
\hline Age & 5513 & 2.626 & 2.708 & 3.932 & 0.000 & 0.450 \\
\hline Size & 5513 & 21.802 & 21.612 & 28.509 & 18.435 & 1.223 \\
\hline Sales Growth & 5513 & 0.231 & 0.144 & 56.174 & -0.971 & 1.177 \\
\hline Board Size & 5513 & 2.121 & 2.197 & 2.890 & 1.386 & 0.195 \\
\hline IndBoard Ratio & 5513 & 0.375 & 0.333 & 0.800 & 0.125 & 0.057 \\
\hline ROA & 5513 & 0.063 & 0.061 & 0.484 & -2.820 & 0.068 \\
\hline Booklev & 5513 & 0.341 & 0.312 & 0.993 & 0.013 & 0.192 \\
\hline Cash Flow & 5513 & 0.039 & 0.040 & 0.475 & -0.670 & 0.072 \\
\hline Tangibility & 5513 & 0.197 & 0.166 & 0.937 & 0.000 & 0.144 \\
\hline
\end{tabular}

The symbol Tobin's $\mathrm{Q}_{\mathrm{i} \text { t: }}$ denotes company performances, $P O L$ the dummy variable for political connections. The under-script I indicates the i-th

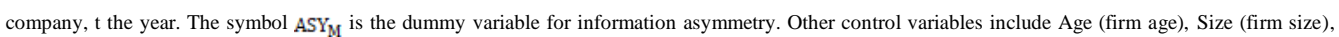
Sales Growth (annual growth of revenues), Board Size (number of directors on the board), IndBoard Ratio (board independence), ROA (return on assets), Booklev (leverage), Cash Flow (cashflows), Tangibility (tangible assets).

This paper conducts a panel data regression in the analysis of the influence of the anti-corruption clause, political connections, and information asymmetry on the performance of listed companies in China. The research findings are shown in the tables 2 and table 3 .

\section{A. Influence of Political Connections on Company Performances}

The first step is to explore the effect of political connections on company performances. The empirical results are presented in Table 2. Model 1 analyzes the impact of political connections on company performances. As shown in the table, political connections have a negative and significant influence on company performances $(\beta=-0.351, \mathrm{P}=0.082)$, indicating that political connections weaken company performances. This paper believes that if the cost of political connections outweighs the benefits, it will have adverse influence on company performances. In the context of economics, politically connected entrepreneurs will leverage their connections for personal gains. This will bump up company costs and drag down efficiency [20]. As far as company decisions are concerned, political connections also have undue weight on management. Yuan (2011) contends that government officials encourage and force politically connected companies to hire more employees [21]. They influence the decisions by these companies, to help resolve the government's political issues in employment. As a result, hiring becomes less efficient and most costly. Therefore, political connected companies report relatively poor performances. 
TABLE II. MUlTiVARIATE ANALYSIS

\begin{tabular}{|c|c|c|c|c|}
\hline Variables & Model 1 & Model 2 & \begin{tabular}{|c|} 
Model 3 \\
$(\mathbf{A S Y}$ _M=1) \\
\end{tabular} & $\begin{array}{c}\text { Model 4 } \\
\text { (ASY_M=0) } \\
\end{array}$ \\
\hline \multirow[t]{2}{*}{$\mathrm{C}$} & $20.615 * * *$ & $22.133 * * *$ & $21.870^{* * *}$ & $19.111 * * *$ \\
\hline & $(20.059)$ & $(9.994)$ & $(14.986)$ & $(15.287)$ \\
\hline \multirow[t]{2}{*}{ POL } & $-0.351 * * *$ & & $-0.636 * * *$ & -0.223 \\
\hline & $(-2.775)$ & & $(-3.207)$ & $(-1.415)$ \\
\hline \multirow[t]{2}{*}{ ASY_M } & & $-0.187 * * *$ & & \\
\hline & & $(-3.017)$ & & \\
\hline \multirow[t]{2}{*}{ AGE } & -0.025 & 0.056 & -0.183 & 0.134 \\
\hline & $(-0.328)$ & $(0.657)$ & $(-1.628)$ & $(1.401)$ \\
\hline \multirow[t]{2}{*}{ SIZE } & $-0.653 * * *$ & $-0.850 * * *$ & $-0.645 * * *$ & $-0.697 * * *$ \\
\hline & $(-16.013)$ & $(-9.026)$ & $(-11.013)$ & $(-14.017)$ \\
\hline \multirow[t]{2}{*}{ SALES_GROWTH } & $0.073 * * *$ & $0.076^{* * * *}$ & $0.079 * *$ & $0.068 * *$ \\
\hline & $(2.913)$ & $(2.802)$ & $(2.158)$ & $(2.111)$ \\
\hline \multirow[t]{2}{*}{ BOARD_SIZE } & $-1.381 * * *$ & -0.273 & $-1.626 * * *$ & $-0.804 * * *$ \\
\hline & $(-5.820)$ & $(-0.845)$ & $(-4.780)$ & $(-2.713)$ \\
\hline \multirow[t]{2}{*}{ INDBOARD_RATIO } & 0.634 & -0.110 & -0.249 & $2.355 * *$ \\
\hline & $(0.825)$ & $(-0.121)$ & $(-0.214)$ & $(2.523)$ \\
\hline \multirow[t]{2}{*}{ ROA } & $2.152 * * *$ & $6.923 * * *$ & 0.916 & $5.393 * * *$ \\
\hline & $(4.254)$ & $(10.089)$ & $(1.453)$ & $(5.903)$ \\
\hline \multirow[t]{2}{*}{ BOOKLEV } & 0.022 & $0.973 * * *$ & -0.181 & -0.122 \\
\hline & $(0.090)$ & $(2.873)$ & $(-0.525)$ & $(-0.391)$ \\
\hline \multirow[t]{2}{*}{ CASH_FLOW } & $5.396 * * *$ & 0.766 & 5.310 *** & $5.762 * * *$ \\
\hline & $(11.097)$ & $(1.496)$ & $(7.197)$ & $(8.918)$ \\
\hline \multirow[t]{2}{*}{ TANGIBILITY } & $-2.047 * * *$ & $-1.809 * * *$ & $-1.945 * *$ & $-2.380 * * *$ \\
\hline & $(-7.413)$ & $(-4.226)$ & $(-5.026)$ & $(-6.707)$ \\
\hline Year Effects & Yes & Yes & No & No \\
\hline Firm Effects & Yes & Yes & Yes & Yes \\
\hline Ajusted $\mathbb{R}^{2}$ & 0.115 & 0.592 & 0.126 & 0.159 \\
\hline F-statistic & 72.340 & 5.390 & 37.303 & 57.421 \\
\hline Obs & 5,513 & 5,513 & 2,527 & 2,986 \\
\hline
\end{tabular}

$\mathrm{N}$ otes: 1 . The symbol Tobin's $\mathrm{Q}_{\mathrm{i}, \mathrm{t}}$ denotes company performances, $P O L$ the dummy variable for political connections. The under-script I indicates the i-th company, t the year. The symbol $A S \mathrm{Y}_{\mathrm{M}}$ is the dummy variable for information asymmetry. Other control variables include Age (firm age), Size (firm size), Sales Growth (annual growth of revenues), Board Size (number of directors on the board), IndBoard Ratio (board independence), ROA (return on assets), Booklev (leverage), Cash Flow (cashflows), Tangibility (tangible assets). 2. *,** and *** represent the significance at $10 \%, 5 \%$ and $1 \%$ levels,

\section{B. Influence of Information Asymmetry on Company Performances}

The next step is to explore the effect of information asymmetry on company performances. The empirical results are summarized in Table 3 Model 2. Model 2 examines the impact of information asymmetry on company performances. As shown in the table, information asymmetry has an adverse influence on company performances $(\beta=-0.187, \mathrm{P}=0.003)$, indicating that information asymmetry reduces company performances. This is possibly because a high level of information asymmetry means no suitable oversight to keep management in check. It gives opportunities for managers to seek personal gains and becomes the recipe for overinvestments or under-investments (Myers and Majluf, 1984). All these factors undermine company performances.

\section{Influence of Political Connections and Information Asymmetry on Company Performances}

To conduct the empirical study on the influence of political connections and information asymmetry on company performances, this paper divides the sample into two groups, one with high levels of information asymmetry and the other with low levels of information asymmetry, by using the median as the dividing point. Statistical tests are conducted on these two groups regarding the relation between political connections and company performances, as shown in Model 3 and Model 4. Model 3 shows the test results on the companies with high levels of information asymmetry. According to Model 3, the combination of political connections and high levels of information asymmetry (IF ASY_M=1) has a significant and negative effect on company performances $(\beta=-0.636$, $\mathrm{P}=0.001$ ). Model 4 tests the influence of low levels of information asymmetry together with political connections. The result is not significant. In sum, political connections undermine company performances when information asymmetry is high. In other words, the influence of political 
connections on company performances is through information asymmetry. This suggests that the information complexity as the content of political connections deepens the information asymmetry between managers and investors and lowers the value of firms.

\section{Influence of the Anti-Corruption Clause, Political Connections, and Information Asymmetry on Company Performances}

The empirical findings on the influence of the anticorruption clause, political connections, and information asymmetry on company performances are shown in Table 4.3 Model 1 and Model 2. This paper divides the sample into two groups, one with high levels of information asymmetry and the other with low levels of information asymmetry, in order to test the political connections and company performance of these two groups before and after the anti-corruption clause. Model 1 shows the influence of the anti-corruption clause, political connections, and high levels of information asymmetry on company performances. The results in Model 1 indicate that high levels of information asymmetry (IF ASY_M=1) is significantly and positively correlated with company performances after the anti-corruption clause $(\beta=1.138$, $\mathrm{P}=0.05)$. This implies that politically connected companies with high levels of information asymmetry enjoy improved company performances in the wake of the anti-corruption clause. This paper argues that political resources with high levels of information asymmetry after the anti-corruption clause becomes a rare, and not imitable core resource and value creator. Model 2 presents the test results on the politically connected companies with low levels of information asymmetry (IF ASY_M=0) post the anti-corruption clause. The table shows that the effect on company performance is not significant. This suggests that the companies with low levels of information asymmetry do not respond much to the anticorruption clause. Given the relative transparency of these companies, there are fewer problems associated with corrupt government officials. Even after the implementation of the anti-corruption clause, company performances are not affected much. These empirical findings suggest $\mathrm{H} 1$ that the anticorruption clause, political connections, and information asymmetry have influence on company performances.

TABLE III. MULTIVARIATE ANALYSIS

\begin{tabular}{|c|c|c|}
\hline Variables & $\begin{array}{c}\text { Model 1 } \\
\text { (ASY_M=1) }\end{array}$ & $\begin{array}{c}\text { Model 2 } \\
\left(\mathbf{A S Y} \_M=0\right)\end{array}$ \\
\hline \multirow[t]{2}{*}{ C } & $25.568 * * * *$ & $22.817 * *$ \\
\hline & $(5.948)$ & $(2.173)$ \\
\hline \multirow[t]{2}{*}{ POL } & -0.153 & -0.236 \\
\hline & $(-0.374)$ & $(-0.946)$ \\
\hline \multirow[t]{2}{*}{ ANTI } & $2.023 * * *$ & 1.060 \\
\hline & $(8.975)$ & $(2.458)$ \\
\hline \multirow[t]{2}{*}{ POL*ANTI } & $1.138^{* *}$ & 0.984 \\
\hline & $(2.332)$ & $(0.738)$ \\
\hline \multirow[t]{2}{*}{ AGE_C } & -0.001 & $0.219 * *$ \\
\hline & $(-0.004)$ & $(2.287)$ \\
\hline \multirow[t]{2}{*}{ SIZE } & $-0.989 * * *$ & $-0.946^{*}$ \\
\hline & $(-5.366)$ & $(-1.949)$ \\
\hline \multirow[t]{2}{*}{ SALES_GROWTH } & 0.092 & 0.039 \\
\hline & (1.194) & $(0.895)$ \\
\hline \multirow[t]{2}{*}{ BOARD_SIZE } & -0.752 & -0.166 \\
\hline & $(-1.112)$ & $(-0.375)$ \\
\hline \multirow[t]{2}{*}{ INDBOARD_RATIO } & -1.470 & 1.018 \\
\hline & $(-0.739)$ & $(0.621)$ \\
\hline \multirow[t]{2}{*}{ ROA } & $4.151 * * *$ & $6.222 * * *$ \\
\hline & $(3.506)$ & $(4.158)$ \\
\hline \multirow[t]{2}{*}{ BOOKLEV } & 0.927 & -0.982 \\
\hline & $(1.347)$ & $(-1.468)$ \\
\hline \multirow[t]{2}{*}{ CASH_FLOW } & -0.324 & $4.523^{*}$ \\
\hline & $(0.736)$ & $(1.793)$ \\
\hline \multirow[t]{2}{*}{ TANGIBILITY } & $-3.016 * * *$ & $-1.880 * *$ \\
\hline & $(-3.576)$ & $(-2.367)$ \\
\hline Year Effects & No & No \\
\hline Firm Effects & Yes & Yes \\
\hline Ajusted $\mathbb{R}^{2}$ & 0.412 & 0.555 \\
\hline F-statistic & 2.538 & 3.515 \\
\hline Obs & 2,527 & 2,986 \\
\hline
\end{tabular}

Notes: 1. The symbol Tobiñ ${ }^{\infty} s Q_{i-\tau}$ denotes company performances, $P O E$ the dummy variable for political connections. The under-script I indicates the i-th company, $t$ the year. The symbol ASY is the dummy variable for information asymmetry, $P O E \times A S Y_{\mathrm{m}}$ the interaction between political connections and information asymmetry. Other control variables include Age (firm age), Size (firm size), Sales Growth (annual growth of revenues), Board Size (number of directors on the board), IndBoard Ratio (board independence), ROA (return on assets), Booklev (leverage), Cash Flow (cashflows), 


\section{CONCLUSIONS}

This paper examines the influence of the anti-corruption clause, ownership structures, political connections, and information asymmetry on company performances. The companies listed in the Shanghai Stock Exchange and the Shenzhen Stock Exchange are sampled for empirical analysis. Based on the literature review, this paper develops hypotheses: The anti-corruption clause affects the relation among political connections, information asymmetry and company performances.

The empirical findings of this paper suggest that political connections have positive and significant influence on company performances with the companies of high levels of information asymmetry after the promulgation of the anticorruption clause. This implies that the anti-corruption clause can cleanse the dirt of corruptions resultant from political connections and allow politically connected resources to work their complexity and inimitability by enhancing company performances. As far as ownership structures are concerned, this paper observes that the performance of state-owned enterprises and family enterprises is positive under the anticorruption clause. The influence on the companies owned by domestic institutions and foreign parents is limited. This suggests the anti-corruption clause has varied influence as a result of governance characteristics under different ownership structures. The conclusion of this paper has profound implications to academic research and practical management. Academically, the research findings of this paper highlight the influence of political connections on company performance should be examined in the context of hidden costs. When it comes to management in the emerging market, this paper posits that corruption crackdown helps companies to access external resources more efficiently and this in turn will enhance company performances.

\section{REFERENCES}

[1] M. Bertrand, F. Kramarz, A. Schoar, and D. Thesmar, "Politically Connected CEOs and Corporate Outcomes: Evidence from France," Unpubl. Manuscr., 2004

[2] N. Xu, X. Xu, and Q. Yuan, "Political Connections, Financing Friction, and Corporate Investment: Evidence from Chinese Listed Family Firms," Eur. Financ. Manag., vol. 19, no. 4, pp. 675-702, 2013.

[3] M. Faccio, "Politically Connected Firms," Am. Econ. Rev., vol. 96, no. 1 , pp. 369-386, 2006
[4] C.J.P. Chen, Y. Ding, and C.F. Kim, "High-Level Politically Connected Firms, Corruption, and Analyst Forecast Accuracy around the World," J. Int. Bus. Stud., vol. 41, no. 9, pp. 1505-1524, 2010.

[5] A.G. Hu and Y. Guo, "Comprehensive Strategy and System Design of Prevention and Control of Corruption in Transition Period," Manage. World, vol. 6, pp. 44-55, 2001.

[6] R. Fisman and J. Svensson, "Are Corruption and Taxation Really Harmful to Growth? Firm Level Evidence,” J. Dev. Econ., vol. 83, no. 1, pp. 63-75, 2007.

[7] S. Agarwal, W. Qian, A. Seru, and J. Zhang, "Disguised Corruption: Evidence from Consumer Credit in China," J. financ. econ., 2020.

[8] R. Fisman, "Estimating the Value of Political Connections," Am. Econ. Rev., vol. 91, no. 4, pp. 1095-1102, 2001.

[9] Y. Hu, C. Wang, G. Xiao, and J. Zeng, "The Value of Politica Connections in Opaque Firms: Evidence from China's File 18," PacificBasin Financ. J., vol. 55, pp. 329-351, 2019.

[10] D.C. Clarke, "Corporate Governance in China: An Overview," Donald C. Clarke," Corp. Gov. China An Overview", China Econ. Rev., vol. 14, pp. 494-507, 2003.

[11] X. Huafang and Y. Jianguo, "Ownership Structure, Board Composition and Corporate Voluntary Disclosure,” Manag. Audit. J., 2007.

[12] L. Xu, Types of large shareholders, corporate governance, and firm performance: evidence from China's listed companies. Hong Kong Polytechnic University (Hong Kong), 2004.

[13] L. Wang, "Protection or Expropriation: Politically Connected Independent Directors in China," J. Bank. Financ., vol. 55, pp. 92-106, 2015 .

[14] B. Ke, N. Liu, and S. Tang, "The Effect of Anti-Corruption Campaign on Shareholder Value in a Weak Institutional Environment: Evidence from China," Unpubl. Work. Pap., 2016.

[15] N. Boubakri, J. Cosset, and W. Saffar, "THE IMPACT OF POLITICAL CONNECTIONS ON FIRMS ' OPERATING,” vol. XXXV, no. 3, pp $397-423,2012$

[16] J.P.H. Fan, T.J. Wong, and T. Zhang, "Politically Connected CEOs Corporate Governance , and Post-IPO Performance of China' s Newly Partially Privatized Firms \$,” vol. 84, pp. 330-357, 2007

[17] Z. Su, H. Fung, D. Huang, and C. Shen, "Cash Dividends Expropriation , and Political Connections : Evidence from China," Int Rev. Econ. Financ., vol. 29, pp. 260-272, 2014.

[18] K. Li and X. Zhao, "Asymmetric Information and Dividend Policy," Financ. Manag., vol. 37, no. 4, pp. 673-694, 2008.

[19] W. Drobetz, M.C. Grüninger, and S. Hirschvogl, "Information Asymmetry and the Value of Cash," J. Bank. Financ., vol. 34, no. 9, pp. 2168-2184, 2010

[20] S. Lovett, L.C. Simmons, and R. Kali, "Guanxi versus the Market: Ethics and Efficiency," J. Int. Bus. Stud., vol. 30, no. 2, pp. 231-247, 1999

[21] Q. Yuan, "Public Governance, Political Connectedness, and CEO Turnover: Evidence from Chinese State-Owned Enterprises," 2011. 